\title{
ANALISA PERUBAHAN CUACA DI PULAU SUMATERA AKIBAT KEBAKARAN HUTAN DENGAN DATA WATER VAPOR DARI CITRA SATELIT TERRA MODIS
}

\author{
Oktalia Triananda Lovita ${ }^{1}$, Mokhammad Nur Cahyadi ${ }^{2}$, Muhammad Taufik ${ }^{3}$ \\ ${ }^{1}$ Program Studi Teknik Industri, Politeknik Aceh Selatan, Jl. Merdeka Aceh - Indonesia \\ ${ }^{2,3}$ Teknik Geomatika, FTSP, Institut Teknologi Sepuluh Nopember Surabaya 60111 - Indonesia \\ E-mail: Oktalia.t.lovita@gmail.com
}

\begin{abstract}
Forest fires in Sumatra lead to a very extreme climate changes around the earth, so there would still be a difficult job for atmosphere researchers. This research was conducted to know the weather conditions by determining the condition of Water Vapor (WV) on the island of Sumatra. Monitoring the condition of WV can be done by using remote sensing techniques, by processing the image satellite data namely Terra Modis (Moderate Resolution Imaging Spectroradiometer). Data calculation condition WV, as one of the parameters of dynamic atmosphere. The data comes from Terra Modis satellite image, the data on Canal 2, 5, 17, 18 and 19 with a wavelength range; $0,865 \mathrm{~m}, 1.24 \mathrm{~m}, 0.905 \mathrm{~m}, 0.936 \mathrm{~m}$ and $0,940 \mathrm{~m}$. From these results obtained from the average value of Water Vapor before and after fires in 2012. Water Vapor taken from TERRA MODIS satellite imagery (y) with a correction factor of 0.9865 . Although the correlation (r) between Water Vapor from MODIS data is high, it can be seen that between Water Vapor in 2012 ranged between 3-8 $\mathrm{cm} .82 \%$, however only about $68 \%$ of Water Vapor MODIS diversity that can be presented by the equation model to approach the actual value of Water Vapor. With these data will greatly affect the weather cycle in Indonesia.
\end{abstract}

Keywords: Climates, Water Vapor, TERRA MODIS

\section{Pendahuluan}

Dalam mencapai keasrian kawasan hutan pemerintah terus berupaya untuk meningkatkan Upaya intensifikasi dapat dilakukan diantaranya dengan pengaturan pemberian pupuk, pengendalian hama penyakit tanaman, dan pengaturan pemberian air irigasi sesuai dengan fase pertumbuhan tanaman. Sedangkan ekstensifikasi dilakukan dengan memperluas areal tanaman. Sementara itu pertumbuhan dan perkembangan suatu tanaman dipengaruhi oleh faktor internal (genetik) dan faktor eksternal, yaitu kondisi tanah dan iklim setempat. Faktor iklim merupakan faktor yang sulit dikendalikan karena bersifat dinamis dari waktu ke waktu. Oleh karenanya diperlukan pemantauan kondisi cuaca yang intensif guna mengantisipasi adanya gangguan terhadap pertumbuhan dan perkembangan tanaman di suatu areal perhutanan.

Pemantauan kondisi tanaman dan kondisi cuaca dalam skala luas dan real time dapat dilakukan dengan menggunakan teknologi penginderaan jauh, salah satunya dengan satelit Terra/Aqua yang membawa sensor MODIS (Moderate Resolution Imaging Spektroradiometer). Satelit ini mampu meliput areal dengan luasan $2330 \mathrm{~km}$. Selain itu satelit ini dilengkapi dengan 36 kanal dan mempunyai tiga. jenis resolusi spasial, yaitu $250 \mathrm{~m}$, $500 \mathrm{~m}$ dan $1000 \mathrm{~m}$. Satelit ini mempunyai kemampuan meliput tempat yang sama setiap 1-2 hari. Pemanfaatan data MODIS untuk pemantauan kondisi Hutan di Pulau Sumatera. Sedangkan penelitian mengenai pemantauan kondisi cuaca dari data MODIS di Indonesia belum banyak dilakukan. Salah satu kondisi atmosfer yang dapat diturunkan dari data MODIS adalah precipitable water Melalui pendekatan jumlah Water Vapor di atmosfer $^{[3]}$.

Berdasarkan uraian di atas, maka penelitian ini dilakukan untuk mengkaji Water Vapor dari data MODIS di wilayah Pulau Sumatera. Diharapkan hasil penelitian ini dapat memberikan informasi awal kondisi cuaca secara spasial untuk kemudian dianalisis dan dikembangkan lebih lanjut oleh instansi pemerintah terkait (Departemen Kehutanan) dalam upaya-upaya penyelamatan tanaman flora dan fauna khususnya di Pulau Sumatera.

\section{Konsep Dasar Penginderaan Jauh}

Penginderaan jauh adalah pengetahuan dan seni untuk mendapatkan informasi tentang obyek, area atau fenomena dengan analisis dari data yang diperoleh dengan peralatan tanpa melakukan kontak langsung dengan obyek, area atau fenomena yang diamati. Data yang diperoleh dari penginderaan jauh dapat berbentuk hasil dari variasi daya, gelombang bunyi atau energi elektromagnetik. Sebagai contoh 
grafimeter memperoleh data dari variasi daya tarik bumi (gravitasi), sonar pada sistem navigasi memperoleh data dari gelombang bunyi dan mata memperoleh data dari energi elektromagnetik. ${ }^{\text {[7] }}$

Prinsip Gelombang Elektromagnetik dan Sumber Energi

Spektrum radiasi elektromagnetik merupakan rentang menyeluruh dari radiasi gelombang elektromagnetik, mulai dari panjang gelombang yang terpanjang (gelombang radio) sampai yang terpendek (sinar gamma) yang merupakan produk dari atomatom radioaktif. Perbedaan mendasar dari gelombang - gelombang ini terletak pada panjang gelombangnya yang berhubungan langsung dengan energi yang dibawa oleh gelombang tersebut. Semakin pendek panjang gelombang dari suatu radiasi, akan semakin tinggi energinya ${ }^{[1]}$.

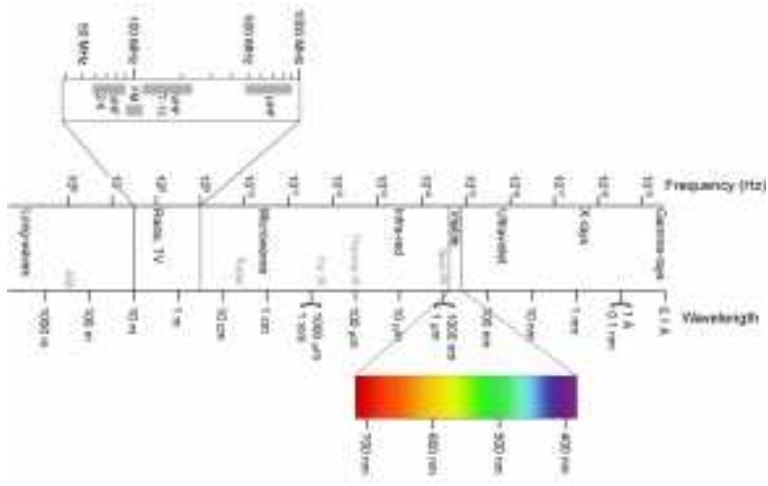

Gambar 1. Panjang Gelombang pada Spektrum Elektromagnetik

\section{Satelit TERRA MODIS}

Satelit EOS AM, yang akhir-akhir ini dinamakan TERRA, diluncurkan pada Desember 1999. TERRA membawa lima instrumen remote sensing yang mencakup MODIS dan ASTER. (Advanced Spaceborn Thermal Emission and Reflectance Radiometer) ASTER adalah sebuah spektrometer citra beresolusi tinggi. Instrumen ASTER didesain dengan tiga band pada range spektral (visible dan near-infrared) VNIR dengan resolusi $15 \mathrm{~m}$, enam band pada (spektral short-wave infrared) SWIR dengan resolusi $30 \mathrm{~m}$ dan lima band pada thermal infrared dengan resolusi $90 \mathrm{~m}$. Band VNIR dan SWIR mempunyai lebar band spektral pada orde 10. Dengan penempatan (pointing) pada target yang sama dua kali, ASTER dapat mendapatkan citra stereo beresolusi tinggi. Cakupan scan dari citra adalah $60 \mathrm{~km}$ dan revisit time sekitar lima hari. MODIS mengamati seluruh permukaan bumi setiap 1 sampai 2 kali dalam sehari dengan whisk-broom scanning imaging radiometer.
Tabel 1. Band MODIS dan Kegunaannya

\begin{tabular}{|c|c|c|}
\hline Knl & Spektrum & Kegunaan \\
\hline 1 & $620-670 \mathrm{~nm}$ & \multirow{6}{*}{$\begin{array}{l}\text { Lahan/ Awan/ } \\
\text { Aerosol Boundaris }\end{array}$} \\
\hline 2 & $841-876 \mathrm{~nm}$ & \\
\hline 3 & $459-479 n m$ & \\
\hline 4 & $545-565 \mathrm{~nm}$ & \\
\hline 5 & $1230-1250 \mathrm{~nm}$ & \\
\hline 6 & $1628-1652 \mathrm{~nm}$ & \\
\hline 7 & $2105-2155 \mathrm{~nm}$ & \multirow{2}{*}{$\begin{array}{l}\text { Lahan/ Awan/ } \\
\text { Aerosol Boundaris }\end{array}$} \\
\hline 8 & $405-420 \mathrm{~nm}$ & \\
\hline 9 & $438-448 \mathrm{~nm}$ & \multirow{8}{*}{$\begin{array}{l}\text { Ocean color/ } \\
\text { Fitoplankton/ } \\
\text { Biogeokimia }\end{array}$} \\
\hline 10 & $483-493 \mathrm{~nm}$ & \\
\hline 11 & $526-536 \mathrm{~nm}$ & \\
\hline 12 & $546-556 \mathrm{~nm}$ & \\
\hline 13 & $662-672 \mathrm{~nm}$ & \\
\hline 14 & $673-683 \mathrm{~nm}$ & \\
\hline 15 & $743-753 \mathrm{~nm}$ & \\
\hline 16 & $862-877 \mathrm{~nm}$ & \\
\hline 17 & $890-920 \mathrm{~nm}$ & \multirow{3}{*}{ Uap Air Atmosfir } \\
\hline 18 & $931-941 \mathrm{~nm}$ & \\
\hline 19 & $915-965 \mathrm{~nm}$ & \\
\hline 20 & $3.660-3.840 \mathrm{um}$ & \multirow{4}{*}{$\begin{array}{l}\text { Surfacel } \\
\text { Temperatur Awan }\end{array}$} \\
\hline 21 & 3.929-3.989 um & \\
\hline 22 & 3.929-3.989 um & \\
\hline 23 & $4.020-4.080 \mathrm{um}$ & \\
\hline 24 & $4.433-4.498 \mathrm{um}$ & \multirow{2}{*}{$\begin{array}{l}\text { Temperatur } \\
\text { Atmosfir }\end{array}$} \\
\hline 25 & $4.482-4.549$ um & \\
\hline 26 & $1.360-1.390 \mathrm{um}$ & \multirow{3}{*}{$\begin{array}{l}\text { Awan Cirrus/ Uap } \\
\text { Air }\end{array}$} \\
\hline 27 & $6.535-6.895 \mathrm{um}$ & \\
\hline 28 & $7.175-7.457 \mathrm{um}$ & \\
\hline 29 & $8.400-8.700$ um & Sifat Awan \\
\hline 30 & $9.580-9.880 \mathrm{um}$ & Ozone \\
\hline 31 & $10.780-11.280 \mathrm{um}$ & \multirow{2}{*}{$\begin{array}{l}\text { Surface/ } \\
\text { Temperatur Awan }\end{array}$} \\
\hline 32 & $11.770-2.270 \mathrm{um}$ & \\
\hline 33 & $13.185-13.485$ um & \multirow{4}{*}{ Cloud Top Altitude } \\
\hline 34 & $13.485-13.785$ um & \\
\hline 35 & 13.785-14.085 um & \\
\hline 36 & $14.085-14.385 \mathrm{um}$ & \\
\hline
\end{tabular}

\section{Precipitable Water Vapor}

Uap air merupakan perwujudan air dalam bentuk gas. Jumlah kandungan uap air di udara dapat disebut dengan kelembaban udara yang dapat diekspresikan dalam jumlah aktualnya, atau konsentrasinya di udara, serta dari rasio jumlah actual. Jika semua uap air di udara pada suatu waktu terkondensasi dan 
jatuh sebagai hujan, maka uap air tersebut dapat dinyatakan sebagai precipitable water Vapor. Jumlah uap air yang terkandung pada mass udara merupakan indikator potensi atmosfer untuk terjadinya presipitasi

Keberadaan uap air di atmosfer dapat dijelaskan dari siklus hidrologi yang terdiri uap air di atmosfer dapat dijelaskan pada Gambar 1. Uap air akan menurun terhadap ketinggian atmosfer, dimana suhu udara menjadi rendah. Semakin tinggi suhu udara, maka kapasitas untuk menampung uap air semakin besar. Sebaliknya, ketika udara bertambah dingin, kapasitas untuk menampung uap air semakin rendah, gumpalan awan semakin besar, dan kemudian akan jatuh sebagai hujan ${ }^{[2]}$

Sebagian besar dari total uap air di atmosfer terdapat di antara permukaan laut hingga $1.5 \mathrm{~km}$ di atas permukaan laut, kemudian sebanyak $5-6 \%$ uap air terdapat di atas ketinggian $5 \mathrm{~km}$ dari permukaan laut, $1 \%$ di stratosfer sekitar $12 \mathrm{~km}$ di atas permukaan laut.

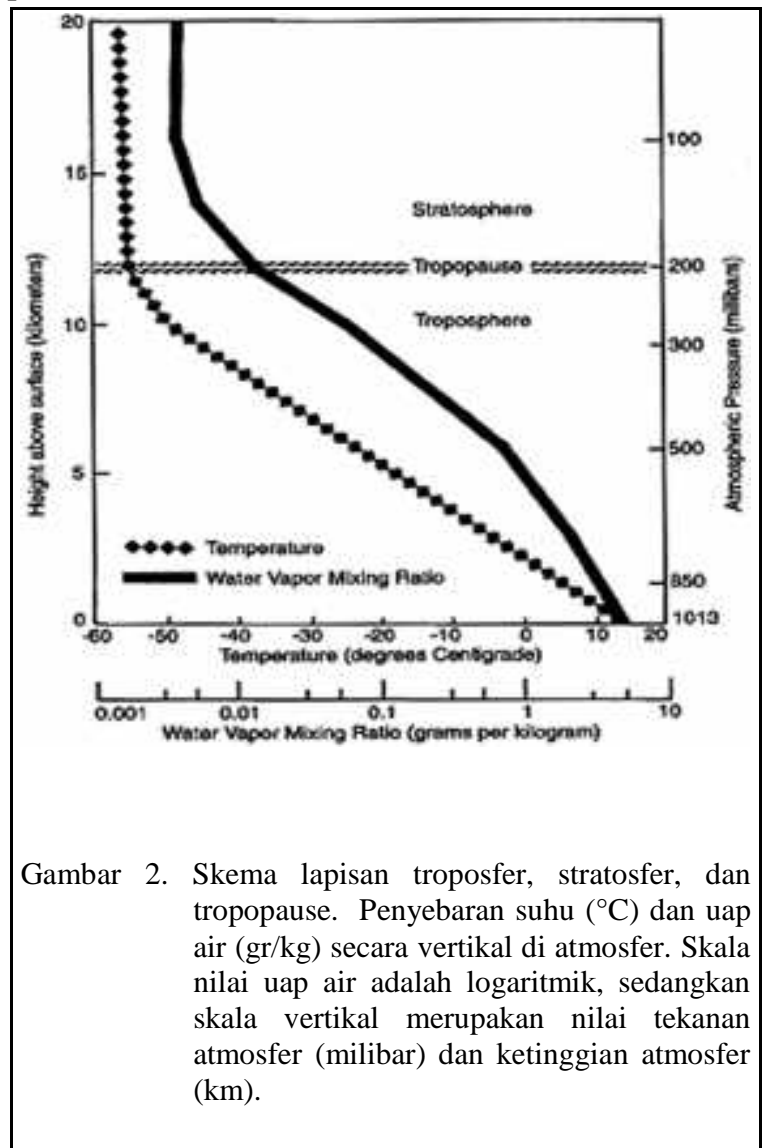

\section{Penurunan Nilai Water Vapor dari Data MODIS}

Metoda penginderaan jauh pada prinsipnya didasarkan pada pendeteksian absorbsi radiasi matahari oleh uap air. Radiasi matahari adalah radiasi matahari yang direflektansikan setelah ditransmisikan ke permukaan bumi ${ }^{[7]}$.

MODIS kanal 2, 5, 17, 18 dan 19 dengan tengah panjang gelombang $0.865,1.24,0.905,0.936$ dan $0.940 \mu \mathrm{m}$ digunakan dalam mengungkap jumlah kandungan uap air (Tabel 1). Kanal $0.865 \mu \mathrm{m}$ dan $1.24 \mu \mathrm{m}$ merupakan kanal yang tidak diserap oleh uap air, sedangkan kanal $0.905 \mu \mathrm{m}, 0.935 \mu \mathrm{m}$, dan $0.940 \mu \mathrm{m}$ merupakan kanal yang diserap oleh uap air [6

Tabel 2. Posisi dan rentang kanal (bandwidht) dari kanal IR MODIS yang digunakan dalam mengungkap uap air.

\begin{tabular}{|c|c|c|c|}
\hline $\begin{array}{c}\text { Kanal } \\
\text { MODIS }\end{array}$ & Poisisi $(\mu \mathrm{m})$ & Bandwith $(\mu \mathrm{m})$ & Sifat \\
\hline 2 & $\mathbf{0 . 8 6 5}$ & $\mathbf{0 . 0 4 0}$ & $\begin{array}{c}\text { Non } \\
\text { absorbsi }\end{array}$ \\
\hline 5 & 1.240 & 0.020 & $\begin{array}{c}\text { Non } \\
\text { absorbsi }\end{array}$ \\
\hline 17 & $\mathbf{0 . 9 0 5}$ & $\mathbf{0 . 0 3 0}$ & Absorbsi \\
\hline 18 & $\mathbf{0 . 9 3 6}$ & $\mathbf{0 . 0 1 0}$ & Absorbsi \\
\hline 19 & $\mathbf{0 . 9 4 0}$ & $\mathbf{0 . 0 5 0}$ & Absorbsi \\
\hline
\end{tabular}

Transmitans uap air atmosfer yang tepat dapat diturunkan dengan melakukan perbandingan reflektans permukaan antara kanal absorbsi dan kanal non-absorbsi, dengan mengabaikan pengaruh variasi reflektansi permukaan. Jika reflektansi permukaan tidak berubah (konstan) dengan berubahnya panjang gelombang, maka perbandingan 2-kanal sudah dapat menurunkan transmitans uap air. Sebagai contoh, transmitans pada kanal $19(0.94 \mu \mathrm{m})$ dapat diperoleh dengan menggunakan Pers (1) berikut:

$\operatorname{Tabs}(0.94 \mu \mathrm{m})=\_$$\rho^{*}(0.940 \mu \mathrm{m})$

$$
\rho *(0.865 \mu \mathrm{m})
$$

dimana Tabs adalah transmitans pada kanal absorbsi; $\rho^{*}$ adalah reflektansi terukur pada sensor. Sebagian besar permukaan daratan ditutupi oleh tanah, bebatuan, vegetasi, salju atau es.

Reflektansi dari permukaan daratan kebanyakan tidak konstan. Berdasarkan penelitian Condit (1970) dalam Kaufman and Gao (1992) dapat diketahui bahwa permukaan yang bebatuan, tanahtanah yang kaya ion besi dan tanah yang mengandung mineral mempunyai nilai reflektansi yang semakin linear pada spektral radiasi Antara 0.8 dan $1.25 \mu \mathrm{m}$. Sehingga, persamaan (1) umumnya tidak berlaku dan digunakan nilai perbandingan 3 kanal, dengan kombinasi 1 kanal absorbsi dan 2 kanal non-absorbsi. Adapun nilai transmitans menggunakan perbandingan 3 kanal dapat dinyatakan sebagai berikut:

$$
\begin{aligned}
& T_{\text {ats }}\left(\lambda_{0}\right)=\frac{\rho^{*}\left(\lambda_{2}\right)}{C_{1} \rho^{*}\left(\lambda_{1}\right)-C_{2} \rho^{*}\left(\lambda_{2}\right)} \\
& C_{1}=\frac{\lambda_{2}-\lambda_{2}}{2_{2} \lambda_{1}} \operatorname{dan} C_{2}=\frac{\lambda_{2}-\lambda_{1}}{\lambda_{2} \lambda_{1}}
\end{aligned}
$$


dimana Tabs adalah transmitans pada kanal absorbsi; $\rho *$ adalah reflektansi terukur pada sensor; $\lambda 0$ adalah nilai tengah panjang gelombang kanal absorbs (kanal 17, 18, 19); $\lambda 1, \lambda 2$ adalah nilai tengah panjang gelombang kanal non-absorbsi (kanal $2,5)$.

Teknik perbandingan 3 kanal dapat digunakan untuk menurunkan jumlah kandungan uap air di atmosfer pada daerah permukaan daratan yang bebas awan, sedangkan teknik perbandingan 2 kanal digunakan pada wilayah sun glint di laut, serta di awan. Wilayah laut yang bebas dari awan dan sun glint menyerap kuat spektral radiasi pada panjang gelombang yang lebih dari $0.8 \mu \mathrm{m}$, terlebih lagi di laut dalam dimana reflektansi spektral Infra Merah Dekat sangat rendah sehingga dapat diabaikan. Oleh karenanya penurunan jumlah kandungan uap air di laut tidak dapat dilakukan ${ }^{[7]}$.

Kaufman dan Gao dalam penelitiannya pada tahun 1992 dan 2003 mengenai penurunan uap air dari satelit, juga menganalisis korelasi antara nilai transmitans uap air dengan jumlah Water Vapor. Korelasi tinggi hubungan antara transmitans uap air pada kanal $19(0.940 \mu \mathrm{m})$ dengan Water Vapor didapatkan dalam bentuk eksponensial ( $\mathrm{r} 2=0.999$ ). Adapun grafik hubungan antara transmitans uap air yang diperoleh dari metode perbandingan 2 kanal, dengan Water Vapor dapat dilihat pada Gambar 3 berikut.

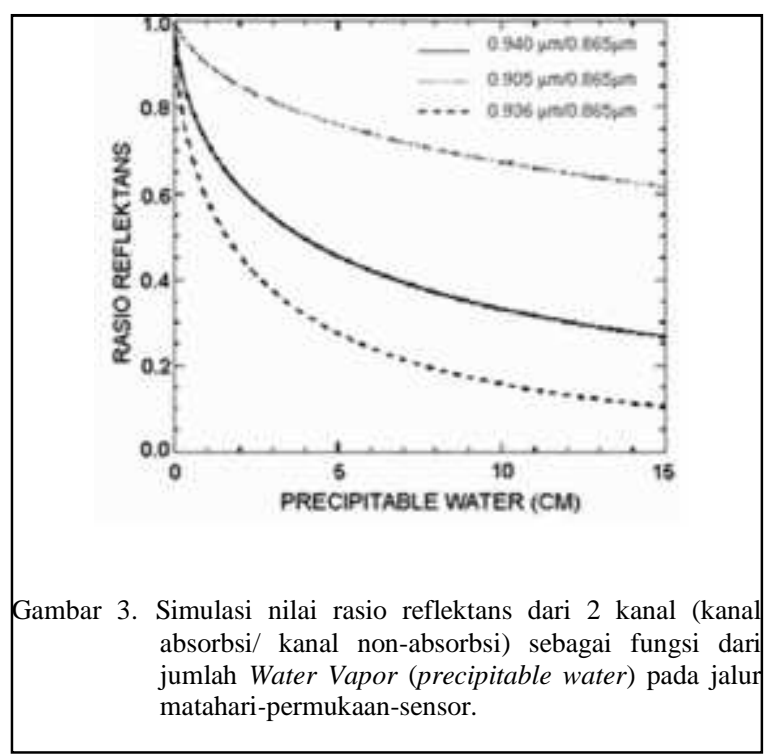

Dalam kondisi atmosferik yang sama, serapan spektral radiasi oleh uap air pada 3 kanal absorbsi masing-masing mempunyai sensivitas yang berbedabeda. Rata-rata jumlah Water Vapor pada suatu kondisi atmosfer dapat diturunkan berdasarkan Pers (3) berikut ${ }^{[10]}$.
$\mathrm{W}=\mathrm{f} 1 \mathrm{~W} 1+\mathrm{f} 2 \mathrm{~W} 2+\mathrm{f} 3 \mathrm{~W} 3$

dimana W1, W2, dan W3 adalah Water Vapor yang diturunkan dari kanal 17 (0.905 $\mu \mathrm{m})$, kanal 18 (0.936 $\mu \mathrm{m})$, dan kanal $19(0.940 \mu \mathrm{m})$. Sedangkan f1, f2, dan f3 merupakan fungsi pembobot masing- masing kanal berdasarkan sensivitas transmitans (Ti) di setiap kanal (i) terhadap Water Vapor (W), dapat digambarkan dalam Pers (4) berikut:

$\mathrm{fi}=\eta \mathrm{i} /(\eta 1+\eta 2+\eta 3) ; \eta \mathrm{i}=|\Delta \mathrm{Ti} / \Delta \mathrm{W}|$

\section{Metode dan Peralatan}

Metode yang digunakan untuk verifikasi hasil pengolahan Water Vapor dari data MODIS adalah dengan menggunakan metode regresi dan korelasi terhadap hasil estimasi Water Vapor dari data MODIS dengan acuan hasil perhitungan Water Vapor dari data Citra Satelit TERRA MODIS. Selain itu juga dilakukan analisis Water Vapor di wilayah Pulau Sumatera.

Agar dapat diaplikasikan dalam bidang Kehutanan, maka jumlah kandungan uap air di atmosfer yang diestimasi dari data satelit perlu direpresentasikan dalam nilai uap air pada citra satelit TERRA MODIS Melalui analisis korelasi maka dapat diketahui besarnya kandungan uap air di atmosfer. Metode ini dilakukan untuk mengasilkan nilai uap yang didapat dari nilai citra satelit terra modis.

\section{Peralatan}

Peralatan yang digunakan dalam kegiatan penelitian ini adalah sebagai berikut :

a. Hardware (Perangkat Keras)

- Perangkat PC

- Notebook

- Printer

b. Software (Perangkat Lunak)

- Microsoft Excel 2013

- Microsoft Word 2013

- Microsoft Visio 2007

- Arc Gis 10.3

- ENVI 5.1 

adalah:

Tahapan yang dilaksanakan dalam penelitian ini

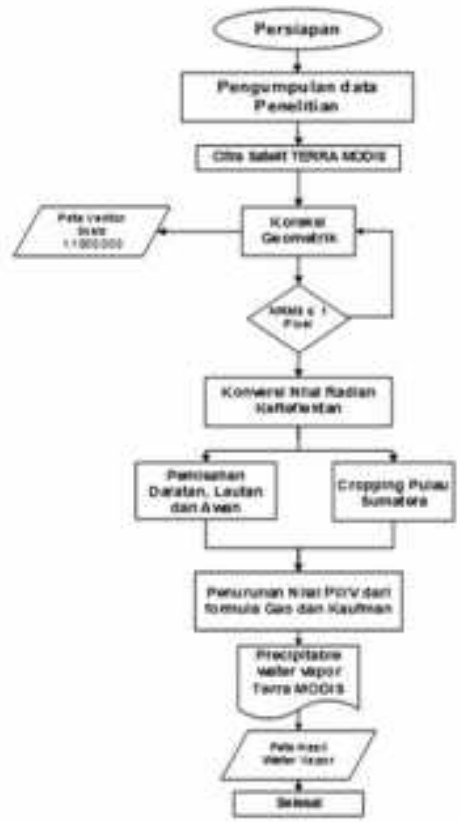

Gambar 4. Diagram Alir Tahapan Penelitian

\section{Hasil dan Pembahasan}

\subsection{Hasil Pengolahan Data Citra}

\subsubsection{Koreksi Geometrik}

Pada penelitian ini, koreksi geometrik dilakukan dengan tujuan untuk mendapatkan citra yang sesuai dengan proyeksi peta dengan membuat GCP pada citra. Pada koreksi geometrik langkah yang dilakukan adalah penentuan titik kontrol tanah (ground control point atau GCP) dengan menggunakan peta yang telah disiapkan sebelumnya, kemudian dilakukan transformasi koordinat dengan menggunakan titik kontrol tanah tersebut. Dalam proses transformasi digunakan 20 titik kontrol (GCP) yang memiliki RMS error <1 piksel. Proses koreksi geometrik dilakukan dengan meletakkan sejumlah titik sesuai dengan koordinat citra dan koordinat geografis. Akurasinya tergantung pada orde polinomial, jumlah dan distribusi titik kontrol tanah. Akurasi koreksi goemetrik biasanya disajikan oleh standar deviasi (Root Mean Square $=$ RMS) per unit piksel pada citra. Akurasi tersebut seharusnya bernilai \pm 1 piksel. Dari proses koreksi bowtie yang telah dilakukan untuk semua data citra modis dapat dilihat pada gambar berikut:

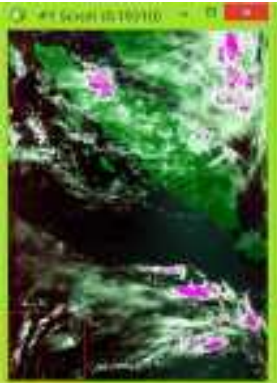

(a)

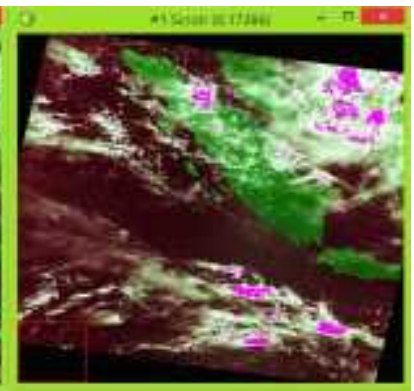

(b)
Gambar 5. (a) Hasil sebelum koreksi Bowtie, (b) Hasil Sesudah koreksi Bowtie Citra Satelit TERRA MODIS, MOD L1b 10 Februari 2012

Dari hasil tersebut dapat dilihat bahwa citra sebelum dan sesudah koreksi berbeda posisi dan bentuknya, tujuan dari koreksi bowtie dilakukan untuk menghilangkan duplikasi data pada baris-baris tertentu, terutama yang jauh dari nadir. Pada proses georeferensi ini dilakukan pemilihan band yang akan kita gunakan dalam pengolahan algoritma untuk mengihtung nilai precipitable water vapor. Sehingga data yang digeoreferensi tidak memilih semua band. Kanal yang digunakan pada citra satelit Terra MODIS untuk menurunkan transmitan uap air antara lain kanal 2 dan kanal 5 sebagai kanal non-absorbs dengan nilai panjang gelombang masing-masing yaitu $0.865 \mu \mathrm{m}$ dan $1.240 \mu \mathrm{m}$. Kanal 17,18 dan 19 digunakan sebagai kanal absorbsi dengan nilai panjang gelombang masing-masing kanal sebesar $0.905 \mu \mathrm{m}$. $0.936 \mu \mathrm{m}$ dan $0.940 \mu \mathrm{m}$. akan tetapi masih ada penyimpangan dari piksel yang menunjukkan posisi sehingga perlu dilakukan proses selanjutnya, yaitu koreksi geometrik.

\subsubsection{Hasil Uji Ketelitian RMSE}

Dari proses koreksi geometrik yang telah dilakukan untuk semua data citra modis dapat dilihat pada keterangan dibawah ini:

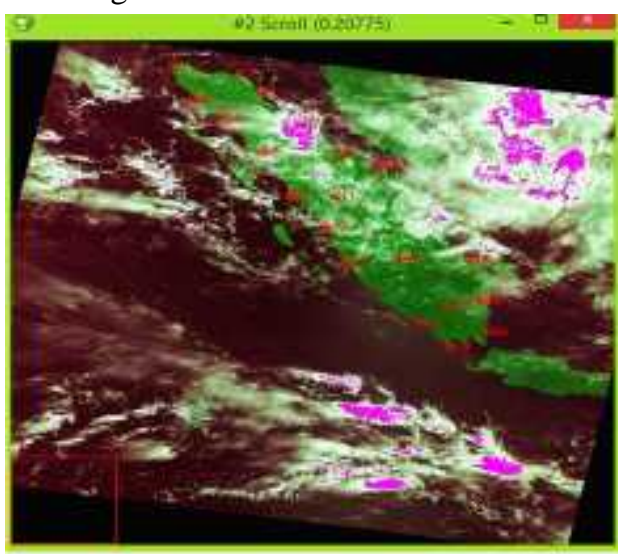

Gambar 6. (a) Hasil GCP Pada Citra Sateli TERRA MODIS, MOD L1b 10 Februari 2012. 
Hal ini dilakukan dikarenakan adanya titik yang mengalami pergeseran dimana titik sampel di laut yang masuk ke dalam piksel. Proses geometrik pada citra pada penelitian ini dilakukan dengan menggunakan peta administrasi Indonesia skala 1:1.000.000. Batas toleransi untuk kesalahan RMSe adalah $=1$ piksel, sehingga jika nilai RMSe saat pengolahan koreksi geometrik lebih besar dari 1 piksel maka harus diulang dalam peletakan titik-titik GCP sampai RMSe dalam koreksi geometrik ini bernilai kurang dari 1 piksel.

Tabel 4. Hasil ERMS Error Citra satelit Terra Modis

\begin{tabular}{|c|c|c|c|c|c|c|c|}
\hline \multirow{2}{*}{ Ties } & \multicolumn{2}{|c|}{ Thile GCP Peta } & \multicolumn{2}{|c|}{$\begin{array}{l}\text { Tíik GCP SIOD } \\
1.18 \text { (103/2012) }\end{array}$} & \multirow{2}{*}{$\begin{array}{l}\text { Erro X } \\
\text { (Pixel) }\end{array}$} & \multirow{2}{*}{$\begin{array}{c}\text { EnvorY } \\
\text { (Pixel) }\end{array}$} & \multirow{2}{*}{$\begin{array}{c}\text { RMAs } \\
\text { (Pirel) }\end{array}$} \\
\hline & $X$ (Plice) & Y (Firel) & $X_{\text {(Pkxt) }}$ & $Y($ Pixtl) & & & \\
\hline 1 & 144800 & 95300 & 1048.00 & 95300 & $0 \infty \infty$ & 0.00 & 020 \\
\hline 2 & 199500 & 115600 & 155500 & 1156000 & 000 & 000 & 034 \\
\hline 3 & 1700.25 & 987.50 & 170025 & 98750 & 0,00 & 0.80 & 0.07 \\
\hline 4 & 175.25 & 133100 & 1775.25 & 1331.00 & 0.00 & 0.00 & 0.00 \\
\hline 5 & 1875.75 & 1167.50 & 1875.75 & 1167.50 & 0.00 & 0.00 & 0.06 \\
\hline 6 & 1835.00 & 1305.50 & $18 B 5, \infty 0$ & $1305: 30$ & 0.00 & 0.00 & 0.00 \\
\hline 7 & 183930 & 154550 & 1859,90 & 154350 & 0.00 & 0,00 & 612 \\
\hline 5 & 2003.60 & 145450 & 2003.00 & $149+50$ & 0.00 & 0.80 & 0.01 \\
\hline 9 & 236500 & 1039.75 & 2365.00 & 1499.75 & 0.00 & 000 & 0.11 \\
\hline 15 & 2387.00 & 1678.75 & 2187.00 & 1678.75 & 0.00 & 0.00 & 000 \\
\hline 11 & 207000 & 124650 & 2057.00 & 184650 & 0,00 & 0.60 & 0.23 \\
\hline 12 & 25050 & 1833.75 & $23,99,00$ & 1833.75 & 0.00 & 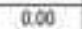 & 0.54 \\
\hline 13 & 2183.25 & 212250 & 2383.25 & 212250 & 0.00 & 0.00 & 0.05 \\
\hline 14 & 2653.75 & 174900 & 2663.75 & 179000 & 0.00 & 0.00 & 0.69 \\
\hline 15 & 24750 & 2039.75 & $2+71.30$ & 2050.75 & 0.00 & 0.00 & 043 \\
\hline 16 & 250020 & 273960 & $25 \times 9.25$ & 223900 & 0,00 & 0.00 & 600 \\
\hline 17 & 2644,90 & 20725 & 264,00 & 2077.25 & 0.00 & 0.00 & 0.60 \\
\hline 11 & 2571.75 & 245575 & 2571.75 & 2185.75 & 0.00 & 0.00 & 0.50 \\
\hline 17 & 2643.73 & 2129.50 & 2643.75 & 212050 & 0.00 & 0.00 & 600 \\
\hline 20 & 2620.75 & 22335 & 2620,73 & 2235.25 & 0,00 & 0,00 & 0.00 \\
\hline \multirow{2}{*}{\multicolumn{7}{|c|}{ Total RUSS Errot }} & 2.37 \\
\hline & & Rat & & inor & & & 0.12 \\
\hline
\end{tabular}

Simber; Hasil Anatisis, 2012

error Proses koreksi geometrik pada citra ini sudah memenuhi toleransi yang batas kesalahan koreksi geometrik kurang dari 1 piksel. Dari hasil koreksi geometrik citra satelit TERRA MODIS diperoleh nilai rata-rata RMS Error untuk citra tahun 2010 sebesar 0.08, tahun 2011 sebesar 0.06, dan tahun 2012 sebesar 0.12. Dalam pengolahan koreksi geometrik di anggap benar apabila nilai dari RMSerror $\leq 1$ pixel yang mana nilai tersebut bertujuan untuk mengurangi kesalahan pada titik kontrol. Apabila nilai dari RMS $\geq 1$ pixel maka titik tersebut harus dikoreksi kembali. Hasil RMSError dari keenam citra satelit TERRA MODIS yang digunakan dalam penelitian memeliki nilai $\leq$, sehingga dapat disimpulkan bahwa hasilnya telah memenuhi kriteria dari koreksi geometrik. Sehingga citra tersebut telah menjadi citra yang terkoreksi secara geometrik.

\subsection{Hasil Precipitable Water Vapor (PWV) dari Citra Satelit Terra MODIS}

Secara umum precipitable water vapor (PWV) yang diestimasi dari data Terra MODIS dengan menggunakan kanal absorsi (17, 18 dan 19) dan non- absorsi (2 dan 5) dapat digunakan untuk memonitoring kondisi cuaca di beberapa wilayah yang tersebar di Pulau Sumatera. Pola distribusi PWV pada lokasi penelitian dapat dilihat pada table berikut ini:

Tabel 3.2 Hasil PWV dari Citra Satelit Terra Modis

\begin{tabular}{|c|c|c|c|c|c|c|}
\hline Doy & Mfin & $\operatorname{Max}$ & Std & $\begin{array}{l}\text { Nilai Rerata } \\
\text { PWV (cm) }\end{array}$ & Tangsal & Keterangan \\
\hline 214 & 1,146 & 3,469 & 0,813 & 1,917 & 01 Agrastus 2012 & Sebelum \\
\hline 222 & 1,747 & 6,786 & 1,883 & 3,985 & 09 Agrustus 2012 & \multirow{3}{*}{ Kehakaran } \\
\hline 223 & 1,280 & 7,000 & 1,810 & 3,466 & 10 Agustur 2012 & \\
\hline 224 & 0,310 & 5,015 & 1.645 & 1.870 & 11 A grastos 2012 & \\
\hline 230 & 2,711 & 5,271 & 0984 & 4.051 & 17 Agustus 2012 & Sesudsh \\
\hline
\end{tabular}

Hasil yang diperoleh terhadap penyebaran precipitable water vapor (PWV) dari pengolahan data citra satelit Terra MODIS, berdasarkan variasi waktu pada Juni 2010 - Agustus 2012 semenjak sebelum, sesudah atau pada saat terjadi keakaran hutan menunjukan nilai water vapor yang tidak jauh berbeda (lihat Tabel 4.2). Pada tanggal 10 Agustus 2012 aktivitas kebakaran hutan mengalami peningkatan, rerata sebaran jumlah water vapor semakin tinggi dengan kisaran nilai rata-rata water vapor adalah $7,000 \mathrm{~cm}$ dibandingkan dengan nilai PWV harian lainnya. Hal ini mungkin disebabkan kebakaran hutan yang menyebar ke lapisan atmosfer masih memperngaruhi proses radiasi matahari ke permukaan bumi.

Selain nilai precipitable water vapor (PWV) dari masing-masing stasiun, perlu juga dibuatkan grafik gabungan nilai precipitable water vapor (PWV) yang diperoleh dari Citra satelit TERRA MODIS untuk mengetahui total nilai precipitable water vapor secara pasti (Gambar 3.2).

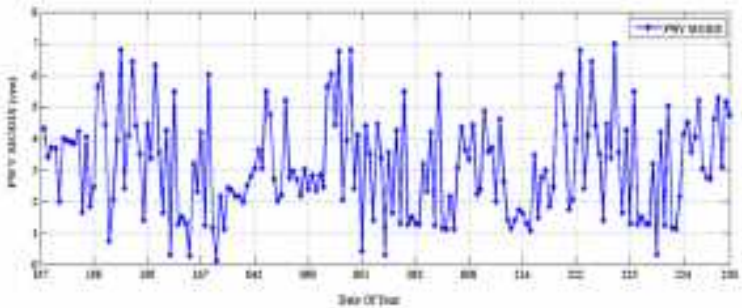

Gambar 7. Grafik Nilai PWV dari pengolahan data dari citra satelit TERRA MODIS

Dari gambar 7 diatas dapat disimpulkan bahwa nilai rerata precipitable water vapor di Pulau Sumatera pada saat kebakaran hutan yang diukur dengan menggunakan teknik Penginderaan jauh, didapatkan nilai minimal PWV adalah $0,121 \mathrm{~cm}$, nilai maximal PWV adalah $7,000 \mathrm{~cm}$, nilai reratanya adalah 2,308 $\mathrm{cm}$ dan standar deviasi (std) adalah $1.325 \mathrm{~cm}$. 


\subsection{Hasil Verifikasi PWV dari Data MODIS dan Data GPS}

Sesuai dengan penyebaran uap air secara vertikal yang lebih banyak berada pada ketinggian antara permukaan laut hingga $1.5 \mathrm{~km}$ di atas permukaan laut, atau pada tekanan atmosfer antara $1013 \mathrm{mb}-$ 850 mb (American Geophysical Union, 2002; Butler, 1998). Sehingga dalam verifikasi nilai PWV dari MODIS terhadap PWV dari GPS digunakan asumsi bahwa hasil estimasi PWV dari MODIS

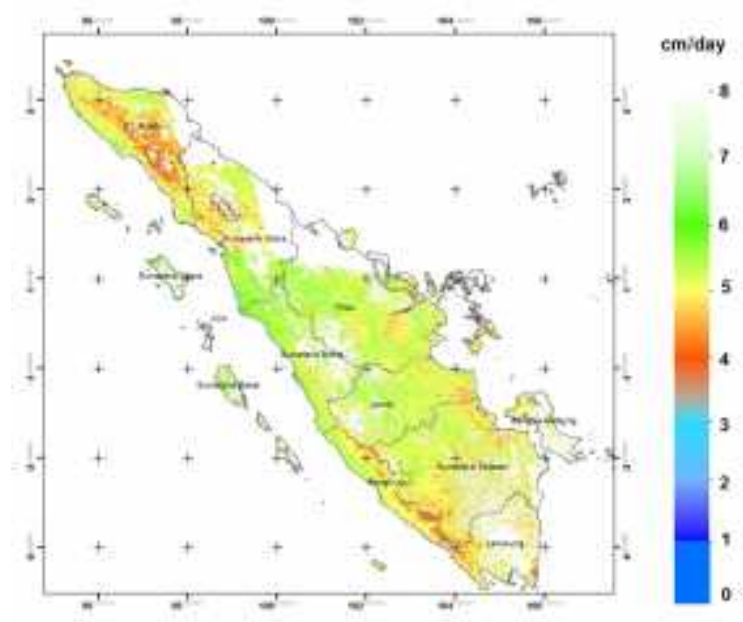

Gambar 8. Peta Informasi Spasial Water Vapor (cm/day) dari data Terra MODIS tanggal 10 Agustus 2012 diwilayah Pulau Sumatera.

Maka analisis WATER VAPOR dari data Citra Satelit TERRA MODIS. Berkisar Antara 3-8 cm. Hasil verifikasi Water Vapor di Pulau Sumatera pada periode tahun 2012 menunjukkan bahwa Water Vapor yang diestimasi dari data MODIS rata-rata mempunyai nilai simpangan baku sebesar $\pm 1.6 \mathrm{~cm}$

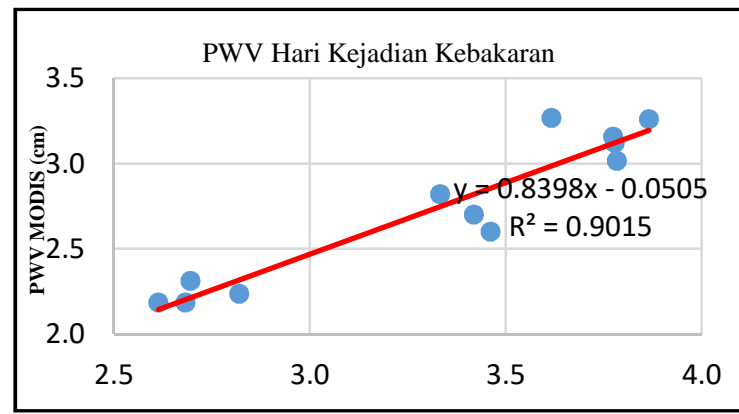

Gambar 9. Hasil perbedaan Antara PWV GPS dan PWV Citra Sateli Terra Modis dipulau Sumatera pada tahun 2012.

Dari grafik diatas menunjukkan hasil rentang kisaran water vapour pada tahun 2012, Analisis ini dilakukan dengan melihat pola distribusi harian. Nilai variasi spasial PWV ini didapatkan dari nilai rerata
PWV, maka diasumsikan bahwa efek dari interpolasi karena sebaran water vapour yang kurang rapat dianggap tidak berpengaruh. Pada (Gambar 3.4) dapat dilihat bahwa pada peta spasial yang ditampilkan memiliki pola distribusi PWV yang cukup rendah, yaitu $\pm 3-8 \mathrm{~cm}$. untuk mengetahui besar korelasi antara dua variable ini. Dari hasil perhitungan menggunakan regression Linier didapatkan nilai korelasi 7,04\%. Hal ini karena proses pergerakan kandungan uap air yang dipengaruhi oleh fenomena siklus Monsun AsiaAustralia juga karena perbedaan kondisi topografi. Sehingga dapat disimpulkan bahwa keadaan topografi mempengaruhi pola distribusi PWV

\section{Kesimpulan}

Dari penelitian ini dapat disimpulkan beberapa informasi yang penting, yaitu antara lain:

1. Secara umum Precipitable Water Vapor (PWV) yang diestimasi dari data MODIS Penyebaran PWV dari MODIS mempunyai korelasi sangat tinggi $\left(r^{2}=0.2714\right)$, dimana PWV cenderung menurun dengan semakin tingginya topografi suatu wilayah. Maka semakin meningkat suhu dipermukaan ketika kebakaran hutan melanda. MODIS mengestimasi kelembaban sekitar $\pm 54-77 \%$. Secara umum kondisi yang dapat diterima oleh manusia sekitar 30-54\%, dimana manusia merasakan kenyamanan nya. Oleh karena itu kebakaran hutan yang melanda pulau sumatera sangat mengganggu aktifitas manusia.

2. Variasi temporal kandungan uap air di Bakosurtanal, Jakarta, Nayang Tecnologycal University, Singapura, Air Bangis Sumatera, Padang, Jambi, Lunnang, Sumatera Barat, Lampung, Manna, Bengkulu, Biouti, Nias, Kp. Mentawai, Sampali Medan dan ujung muloh banda aceh. Pada tahun 2012 berkisar antara $\pm 3-8 \mathrm{~cm} /$ day $(42-98 \%)$

\section{Daftar Pustaka}

[1] Abidin, H., Jones, A., Kahar, J 2011. Survey dengan GPS. Bandung: Institut Teknologi Bandung.

[2] Asdak, C, 2002. Hidrologi dan pengelolaan daerah aliran sungai. Gadjah Mada University Press American Geophysical Union, 2002. Water vapor in the climate system. Florida Ave., N.W., Washington, DC 20009

[3] Butler, B, 1998. Precipitable Water at KP 1993 1998. National Radio Astronomy Observatory

[4] Gao, B.C. and Y. J. Kaufman, 2003. Water vapor retrievals using moderate resolution imaging spectroradiometer (MODIS) near-infrared channels. J. Geophys Research. Vol. 108, No. D13,4389: 1 - 10

[5] Gao, B.C., P. Yang, G. Guo, S.K. Park, W.J. Wiscombe, and B. Chen, 2003. Measurements of 
water vapor and high clouds over the Tibetan Plateau with the Terra MODIS Instrument. IEEE Trans.

Geosci. Remote Sens. Vol. 41, No.4: 895 -900

[6] Kaufman, Y.J, and B.C. Gao, 1992. Remote sensing of water vapor in the near IR from EOS/MODIS. IEEE Trans. Geosci. Remote Sens. Vol. 30, No.5: $871-884$

[7] Lillesand dan Kiefer. 1997. Penginderaan Jauh dan Interpretasi Citra. Dulbahri (Penerjemah). Gadjah Mada University Press, Yogyakarta.

[8] Lillesand, Kiefer, dan Chipman,. 2004. Remote Sensing and Image Interpretation. University of Wisconsin, Madison.

[9] Lim, A., C.W. Chang, S.C. Liew, and L.K. Kwoh, 2002. Computation of atmosferic water vapor map from MODIS data for cloud-free pixels. Centre for Remote Imaging, Snsor and Processing (CRISP). National Univ of Singapore

[10] Sobrino, J.A., J.E. Kharraz, and Z.L. Li, 2003. Surface temperature and water vapor retrieval from MODIS data. Int. J. Remote Sens, Vol. 24, No. $24: 5161-5182$ 